[Agr. Biol. Chem., Vol. 34, No. 4, p. 585 589, 1970]

\title{
On the Relationship between Food Composition and Serine Dehydrase Activity in Rat Liver
}

\author{
Part II. On the Factor of Enzyme Induction by High Protein Diet ${ }^{\dagger}$
}

\author{
By Masaji OgurA \\ Department of Agricultural Chemistry, Faculty of Agriculture, Utsunomiya University, Utsunomiya
}

Received August 30, 1969

\begin{abstract}
Effects of the change of dietary protein on serine dehydrase activity in rat liver have been studied, using egg albumin, casein, rice protein, and wheat gluten as protein source. At $35 \%$ of dietary protein level, the activity induced by egg albumin and casein diets were higher than those by rice protein and wheat gluten diets. Parallel relation was observed between the enzyme activity and the protein intake. These results suggest that the dietary induction of this enzyme are based on the protein intake, which reflects the nutritional quality of dietary protein, rather than merely on the dietary protein level.

The contribution of individual amino acid for the enzyme induction by the egg albumin diet at $35 \%$ level was investigated, and it was concluded that this enzyme induction is dependent not on a specific amino acid but on the combined effect of each amino acid.
\end{abstract}

Serine dehydrase activity in rat liver is known to be controlled by dietary and hormonal factors. ${ }^{1 \sim 71}$ In the previous papers, ${ }^{8,9}$ it was reported that this enzyme activity is mainly controlled by dietary protein and caloric levels, after a comparison with the studies by Peraino and Pitot $^{2}$ and Peraino, Blake, and Pitot. ${ }^{31}$ Peraino et al. reported that the feeding of tryptophan alone pro-

A part of this study was presented at the Annual Meeting of the Agricultural Chemical Society of Japan, held at Nagoya, April 4, 1968.

1) R. A. Freedland and E. H. Avery, J. Biol. Chem., 239, 3357 (1964).

2) C. Peraino and H. C. Pitot, ibid., 239, 4308 (1964).

3) C. Peraino, R. L. Blake and H. C. Pitot, ibid., 240, 3039 (1965).

4) L. Goldstein, W. E. Knox and E. J. Behrman, ibid., 237, 2855 (1962).

5) F. T. Kenny and F. J. Kull, Pro. Natl. Acad, Sci. U.S., 50, 506 (1963).

6) E. Ishikawa, T. Ninagawa and M. Suda, J. Biochem., 57, 506 (1965).

7) M. Suda, Adv. in Enz. Reg., 5, 181 (1967).

8) M. Ogura, Agr. Biol. Chem., 30, 226 (1966).

9) M. Ogura, ibid., 30, 1054 (1966). duced a significant but submaximal induction of this enzyme. The question as to whether this enzyme is usually induced by tryptophan for the most part in the case of high protein feeding remains for further study. The present study is aimed to determine the factor of induction of serine dehydrase by the high protein diet.

Following points were mainly mentioned; 1) Effect on the enzyme activity of the change of dietary protein, 2) Comparison of the enzyme inductivity of individual amino acid in the dietary protein.

\section{MATERIALS AND METHODS}

Animals. Female wealing rats of the Wistar strain weighing about $120 \mathrm{~g}$ were used. Before being fed on the experimental diets, the rats were fed for 3 days on CLEA CE-2 diet (crude protein: 24.00\%), supplied by the Nihon Clea Co., Tokyo. Thereafter, the rats were divided into similar groups of 4 animals each and maintained individually in the wire bottomed cages. The rats were fed on the experimental diets and water ad libitum for 5 days. Body weight and 
food consumption were recorded every day during the experimental period of 5 days.

Materials. Casein, amino acids, and salt mixture were obtained from Tanabe Amino Acid Research Foundation. Egg albumin and wheat gluten were purchased from Koso Chemical Co., Ltd. High protein rice was prepared by digestion of rice with the amylolytic enzyme.101 The preparation containing $46.82 \%$ of crude protein was obtained by this method.

Preparation and assay of enzyme. The preparation of enzyme solution and the assay of enzyme activity were used in the same method as in the previous paper. ${ }^{81}$ Specific activity of enzyme is expressed conveniently as micromoles of product per $\mathrm{g}$ protein per minute.

Experiment 1 . The rats were divided into 8 groups. The composition of experimental diets is summarized in Table I.

Table I. Composition of ExPERIMENTAL Diets ${ }^{a}$ (EXPERIMENT I)

\begin{tabular}{lllllllll}
\hline & \multicolumn{4}{c}{ Group } \\
\cline { 2 - 6 } & I & II & III & IV & V & VI & VII & VIII \\
& & &
\end{tabular}

\begin{tabular}{|c|c|c|c|c|c|c|c|}
\hline Egg albumin & 10.035 .0 & - & - & - & - & - & - \\
\hline Casein & $-\quad-$ & 10.0 & 35.0 & - & - & - & - \\
\hline Rice protein $b$ ) & - & - & - & 10.0 & 35.0 & - & - \\
\hline Gluten & $-\quad-$ & - & - & - & - & 10.0 & 35.0 \\
\hline \multirow[t]{5}{*}{ Corn Starch } & 80.055 .0 & 80.0 & 55.0 & 80.0 & 55.0 & 80.0 & 55.0 \\
\hline & Saltsel & & & 4.0 & & & \\
\hline & Fat ${ }^{d l}$ & & & 5.4 & & & \\
\hline & Vitamin & & & 0.45 & & & \\
\hline & Choline & chlo & & 0.15 & & & \\
\hline
\end{tabular}

a) The values are expressed as per cent of dry diets.

b) Rice protein was prepared by the method described in the text.

c) The percentage composition of salts was described in the previous paper. ${ }^{91}$

d) Lard Ltd.)

e) "Panvitan" powder (Takeda Chemical Industries,

The composition of "Panvitan" was described in the previous paper. ${ }^{81}$

10) R.J. Block, "Amino Acid Handbook," Charles C. Thomas Publisher, 1956, p. 14.

11) R. J. Block, ibid., p, 341, 342, 346.
Experiment II. Eight groups of rats were used. The rats were fed on the diets with the various tryptophan level by addition of L-tryptophan to $10 \%$ protein diets in Exp. I. The supplemental amount of L-tryptophan for each group is shown in Table III, together with the data of tryptophan intake and of enzyme activity in this experiment.

Experiment III. In 35\% protein diets of Exp. I, the content of starch becomes smaller by the increase of protein percentage in the diet than in $10 \%$ protein diets. In Exp. III, therefore, a part of starch in $10 \%$ egg albumin diet was replaced by cellulose powder and the various amino acids were added to make up equivalent to the quantity contained in $35 \%$ egg albumin diet. Namely, this experiment was designed to determine the contribution of each component amino acid for the enzyme induction at $35 \%$ protein diet. Table IV shows the supplemental amount of each amino acid.

\section{RESULTS AND DISCUSSION}

\section{Experiment $I$}

The relationship between enzyme activity and dietary protein is shown in Table II. The enzyme activities at 35\% protein level were remarkably higher (about from ten to twenty times) than those at $10 \%$ protein level in all the protein sources tested. In comparison with the degree of these induced activities, the difference due to the kind of protein source was observed. The activities induced by animal protein diets, such as egg albumin and casein, were significantly higher than those by vegetable protein diets, such as rice protein and wheat gluten. It was indicated as far as tested that, in the same protein level, the degree of enzyme induction may be related to the biological value ${ }^{121}$ of dietary protein, which is given in Table II.

From these results, it can be proposed that the increase of serine dehydrase activity is not only based upon the dietary protein level, but also upon the nutritive value of

12) P. B. Rama Rao, H. W. Norton and B. C. Johnson, J. Nutrition, 82, 88 (1964). 
On the Relationship between Food Composition and Serine Dehydrase Activity in Rat Liver. Part II 587

Table II. Effect of Level and Kind of Dietary Protein on Serine Dehydrase Activity (EXPERIMENT I)

\begin{tabular}{|c|c|c|c|c|c|c|c|}
\hline Group & $\begin{array}{c}\text { Protein } \\
\text { source }\end{array}$ & $\begin{array}{l}\text { Biological } \\
\text { value }^{12 !}\end{array}$ & $\begin{array}{c}\text { Protein level } \\
\%\end{array}$ & $\begin{array}{l}\text { Body weight gains } \\
\text { g/5 days }\end{array}$ & $\begin{array}{l}\text { Food intake } \\
\text { g/s days }\end{array}$ & $\begin{array}{l}\text { Protein intake } \\
\text { g/s days }\end{array}$ & Specific activity \\
\hline I & Egg albumin & 93 & 10 & $33.0 \pm 0.7 a 1$ & $87.1 \pm 4.1^{a)}$ & $8.7 \pm 0.4^{a 1}$ & $3.9 \pm 0.9^{a}$ \\
\hline II & " & & 35 & $32.6 \pm 3.6$ & $79.5 \pm 1.6$ & $27.8 \pm 0.7$ & $87.4 \pm 18.5$ \\
\hline III & Casein & 79 & 10 & $24.4 \pm 2.4$ & $86.0 \pm 1.3$ & $8.6 \pm 0.1$ & $9.1 \pm 1.7$ \\
\hline IV & $" \prime$ & & 35 & $29.8 \pm 2.5$ & $78.6 \pm 4.3$ & $27.5 \pm 1.7$ & $71.7 \pm 2.7$ \\
\hline $\mathrm{V}$ & Rice & 70 & 10 & $7.4 \pm 3.0$ & $65.4 \pm 5.0$ & $6.5 \pm 0.5$ & $5.4 \pm 1.6$ \\
\hline VI & " & & 35 & $8.3 \pm 3.7$ & $57.3 \pm 2.9$ & $20.1 \pm 1.0$ & $64.5 \pm 9.2$ \\
\hline VII & Gluten & 52 & 10 & $3.0 \pm 0.7$ & $63.6 \pm 5.4$ & $6.4 \pm 0.5$ & $4.3 \pm 2.6$ \\
\hline VIII & $"$ & & 35 & $19.7 \pm 2.9$ & $68.1 \pm 2.1$ & $23.8 \pm 0.7$ & $48.3 \pm 10.5$ \\
\hline
\end{tabular}

a) The values represent mean \pm standard error of the mean for a group of 4 rats.

dietary protein. These facts can be interpreted that, as a result of the accelaration of gluconeogenesis in rat liver fed on the superior protein diet, an enzyme activity remarkably increased, because the more protein utilization for animal becomes active, the more energy requirement is increased.

Table II also shows the food intake and the body weight gains in Exp. I. The protein intake was significantly higher in animal protein diets than in vegetable ones. Consequently, it may be more reasonable to assume that this enzyme induction is dependent on the protein intake, which reflects the nutritional quality of dietary protein source.

\section{Experiment $I I$}

Effects of tryptophan supplements on the enzyme activity are shown in Table III. It is interesting, in comparison with the results by Peraino et $a l .^{31}$ before mentioned, that when the various amounts of L-tryptophan were added to each diet of $10 \%$ protein level in Exp. I, and even if the tryptophan intake was more than that at $35 \%$ protein diet (Exp. I), this enzyme activity was not significantly induced in each group. The inconsistency between the result of the present study and that reported by Peraino et al. may possibly be attributed to the difference in experimental condition, since in their study the protein deplet rats which had been forcibly fed free

Table III. Effect of Tryptophan Supplement on Serine Dehydrase Activity (EXPERIMENT II)

\begin{tabular}{|c|c|c|c|c|c|}
\hline Group & $\begin{array}{c}\text { Protein } \\
\text { source }\end{array}$ & $\begin{array}{l}\text { Tryptophan added } a \\
g\end{array}$ & $\begin{array}{c}\text { Tryptophan intake }{ }^{b /} \\
\text { g/6 days }\end{array}$ & $\begin{array}{c}\text { Tryptophan intake in } \\
35 \% \text { level }{ }^{\prime}\end{array}$ & Specific activity \\
\hline I & Egg albumin & 0.250 & $0.35 \pm 0.02$ & $0.42 \pm 0.01$ & $5.8 \pm 0.7$ \\
\hline II & " & 0.400 & $0.40 \pm 0.02$ & & $6.8 \pm 1.6$ \\
\hline III & Casein & 0.250 & $0.27 \pm 0.03$ & $0.41 \pm 0.02$ & $8.2 \pm 3.1$ \\
\hline IV & $"$ & 0.400 & $0.34 \pm 0.03$ & & $10.3 \pm 2.5$ \\
\hline V & Rice & 0.250 & $0.23 \pm 0.03$ & $0.24 \pm 0.03$ & $6.1 \pm 1.4$ \\
\hline VI & $"$ & 0.500 & $0.43 \pm 0.05$ & & $9.4 \pm 0.6$ \\
\hline VII & Gluten & 0.250 & $0.18 \pm 0.02$ & $0.22 \pm 0.01$ & $4.0 \pm 1.0$ \\
\hline VIII & " & 0.665 & $0.43 \pm 0.06$ & & $8.5 \pm 2.1$ \\
\hline
\end{tabular}

a) The values are expressed as grams added to $100 \mathrm{~g}$ of $10 \%$ protein diets in Exp. I (Table I).

b) The intake were calculated based upon the literature of Block.11

e) The values were calculated from the food intake in Exp. I. 
amino acid(s) by stomach tube were used. However, the present experimental method would seem to be suitable for the study on the cause of enzyme induction in rats fed 35 $\%$ protein diets ad libitum.

\section{Experiment III}

As described above, this experiment was aimed to confirm the effect of individual amino acid on the enzyme induction. The response of enzyme activity for each amino acid is given in Table IV.

Since the food intake of each group was

Table IV. Comparison of EfFect of Each Amino ACID ON INDUCTION OF SERINE DEHYdRASE ACTIVITY (EXPERIMENT III)

\begin{tabular}{|c|c|c|c|c|}
\hline Group & Amino ac & ${ }_{\%} \operatorname{added}^{b 1}$ & $\begin{array}{c}\text { Cellulose }^{b} \text {, } \\
\text { powder } \\
\% \%\end{array}$ & $\begin{array}{l}\text { Specific } \\
\text { activity }\end{array}$ \\
\hline$I^{a)}$ & - & - & - & $3.9 \pm 0.9$ \\
\hline II & - & - & 25.00 & $12.9 \pm 2.5$ \\
\hline III & Try & 0.40 & 24.60 & $12.7 \pm 2.6$ \\
\hline IV & Cys & 0.45 & 24.55 & $20.5 \pm 3.3$ \\
\hline V & His & 0.50 & 24.50 & $8.5 \pm 0.7$ \\
\hline VI & Gly & 0.88 & 24.12 & $9.2 \pm 2.6$ \\
\hline VII & Pro & 0.95 & 24.05 & $11.4 \pm 4.9$ \\
\hline VIII & Tyr & 0.98 & 24.02 & $18.2 \pm 2.6$ \\
\hline IX & Thr & 1.05 & 23.95 & $11.5 \pm 3.9$ \\
\hline $\mathrm{X}$ & Met & 1.23 & 23.77 & $19.2 \pm 4.0$ \\
\hline$X I$ & Arg & 1.50 & 23.50 & $8.5 \pm 1.4$ \\
\hline XII & Lys & 1.63 & 23.37 & $7.5 \pm 0.8$ \\
\hline XIII & Ileu & 1.70 & 23.30 & $9.1 \pm 2.7$ \\
\hline XIV & Ala & 1.73 & 23.27 & $9.7 \pm 2.2$ \\
\hline$X V$ & Phe & 1.78 & 23.22 & $4.8 \pm 1.5$ \\
\hline XVI & Ser & 1.85 & 23.15 & $13.4 \pm 4.6$ \\
\hline XVII & $\mathrm{Val}$ & 2.03 & 22.97 & $5.2 \pm 1.0$ \\
\hline XVIII & Leu & 2.25 & 22.75 & $22.8 \pm 7.3$ \\
\hline XIX & Asp & 2.40 & 22.60 & $19.8 \pm 4.2$ \\
\hline $\mathrm{xx}$ & Glu & 3.73 & 22.27 & $19.7 \pm 3.0$ \\
\hline
\end{tabular}

The following common constituents were contained in the diets (\%); corn starch: 55.0, egg albumin: 10.0 , salt mixture: 4.5 , vitamins: 0.45 and choline chloride: 0.15 .

a) Control group (the same group as that fed $10 \%$ egg albumin diet in Exp. I)

b) The supplemental amounts are expressed as per cent of dry diet. almost equal to or slightly higher than tha1 at $35 \%$ egg albumin diet, the intake of eack amino acid in question was in substantia agreement with that of the corresponding amino acid at $35 \%$ egg albumin diet.

The enzyme activity was significantly high. er in Group II than in Group I $(\mathrm{P}<0.05)$. But this enzyme induction due to the replacement of starch by cellulose powder was remarkably less than that due to $35 \%$ protein diet. Furthermore, although the contribution of individual amino acid for the enzyme induction showed a slight difference, any amino acid tested was not concerned with a specific high inductivity. Thus it must be emphasized also in this case that the addition of tryptophan does not show a significant increase of the activity, unlike at $35 \%$ protein diet in Exp. I. From this result, it is assumed that the induction at $35 \%$ protein diet is not based on a specific amino acid, for example, such as tryptophan or serine, but the composite effect of amino acids. As a method to determine this point, the induction by the combination of various amino acids was investigated.

Firstly, when aspartic acid and glutamic acid, which are contained at relatively high level in egg albumin, were combined, the specific activity obtained was approximately additive (Group I in Table V). But these

Table V. Effect of Some Amino Acid Mixture ON SERINE DEHYDRASE ACTIVITY (EXPERIMENT III)

\begin{tabular}{ccccc}
\hline Group & $\begin{array}{c}\text { Amino acid } \\
\text { mixture, }\end{array}$ & $\begin{array}{c}\text { added } \\
\%\end{array}$ & $\begin{array}{c}\text { Cellulose } \\
\text { powder } \\
\%\end{array}$ & $\begin{array}{c}\text { Specific } \\
\text { activity }\end{array}$ \\
\hline I & $\begin{array}{c}\text { Glu, Asp } \\
\text { II }\end{array}$ & $\begin{array}{l}\text { Ser, Thr, Lys } \\
\text { Try, Glu, Asp }\end{array}$ \\
& $\begin{array}{l}\text { Arg, His, Tyr } \\
\text { Arg, His }\end{array}$ & 18.87 & $43.1 \pm 7.2$ \\
III & $\begin{array}{l}\text { Phe, Cys, Met } \\
\text { Leu, Ileu, Val } \\
\text { Gly, Ala, Pro }\end{array}$
\end{tabular}

a) The supplemental amounts of individual amino acid and the other components were equal to those in Table IV. 
On the Relationship between Food Composition and Serine Dehydrase Activity in Rat Liver. Part II 589

combined amino acids do not seem to have a specific action for the enzyme induction, because any relationship between this enzyme activity and the intake of these amino acids was not observed in Exp. I. The intakes of aspartic acid and glutamic acid at 35\% protein diets of Exp. I were $12.5 \pm 0.1 \quad(\mathrm{~g} / 5$ days $)$ in gluten diet, $6.9 \pm 0.1$ in egg albumin and $2.5 \pm 0.1$ in rice, while the numerical order of the enzyme activity was egg albumin, rice, and gluten diet.

Secondly, as shown in Table V, when serine, threonine, lysine, and tryptophan, which are now being studied in each case from various angles as the inducer of this enzyme, and in addition to them, aspartic and glutamic acids were added, the induction was about half as much as that of 35\% protein level. And it was almost similar level to that by the combined addition of remaining amino acids. There is sufficient evidences to justify the conclusion that the induction at $35 \%$ protein level is not dependent upon a specific amino acid.

Recently, it has been reported that this enzyme induction is regulated by insulin and adrenal cortical hormones. Goldstein et al., ${ }^{41}$ Kenny and Kull, ${ }^{51}$ and Ishikawa et al. ${ }^{6)}$ reported that serine dehydrase and tyrosine transaminase were induced by cortisone. Also in the present case, assuming that this induction is directly based on the hormone, it may be said that the combined action of amino acid (or protein) must be considered to be necessary for secretion of this hormone.

Acknowledgements. The author wishes to express his appreciation to Prof. H. Nishi for helpful suggestions, and is indebted to Messrs. K. Enomoto, F. Tomiyama, K. Takamizawa and T. Higuchi in this laboratory for their generous assistance in the course of this study. 